\title{
Potassium Content of Three Grass Species during Winter
}

\author{
R.T. HINNANT AND M.M. KOTHMANN
}

\section{Abstract}

The potassium content of little bluestem (Schizachrium scoparium (Michx.) Nash), kleingrass (Panicum coloratum L.), and brownseed paspalum (Paspalum plicatulum Michx.) declined following plant senescence and frost. The potassium content of herbage of little bluestem and brownseed paspalum reached levels below the requirements of cattle by February during two winters. Kleingrass leaves retained green tissue the first winter yielding higher potassium levels. Little bluestem had reached senescence and had low levels of potassium by November. Herbage of the three species was also subjected to soaking treatments to simulate frost damage and quantify losses due to leaching. Potassium levels declined with soaking in freeze damaged herbage as time of exposure increased. Soaking treatments did not significantly affect the potassium content of fresh live herbage.

Potassium (K) is abundant in most rangeland soils (Woodhouse 1962), and during periods of active growth plants normally contain amounts exceeding the dietary levels of 0.6 to $0.8 \%$ recommended for cattle (Burroughs 1976). Ward (1966) stated that any diet selected by grazing ruminants would probably never be deficient in potassium. Deficiencies have been reported on low forage high concentrate diets (Davis et al. 1964, Emery et al. 1965). However, even high concentrate rations are not believed to pose a deficiency problem since the $\mathrm{K}$ content of most grains is greater than $0.5 \%$ (Church 1971). Dormant grasses may yield K levels below the requirement for cattle causing stress and reduced performance (Kothmann and Hinnant 1976).

Potassium ions within plants do not enter into permanent organic combinations, but exist as highly mobile soluble organic and inorganic salts (Lawton and Cook 1954). Potassium is required by plants for nitrogen and carbohydrate metabolism. activation of various enzymes, control of essential mineral elements, promotion of growth of meristematic tissue, and adjustment of stomatal movement and water relations (Tisdale and Nelson 1968). Free K ions are absorbed by the roots and move to new foliage. Potassium ions move from older dormant tissue in the phloem to the roots and diffuse into the soil (Lawton and Cook 1954). Potassium ions are readily leached from leaves of dormant foliage by rain or dew and are subject to some leaching from living foliage (Tukey and Amlug 1958, Clement et al. 1972).

Potassium functions in animals to maintain osmotic balance, acid-base equilibrium, ionic balance, water balance, and as a cofactor of several enzyme systems, and is an important component of milk. Potassium must be included in the daily ration since it is a very mobile element and there are no appreciable reserves other than in the muscle and nerve cells. Potassium is removed from plasma in the kidneys, which have little capacity for conservation. Renal excretion of $\mathbf{K}$ continues even when body levels are dangerously low (Thompson 1972).

\footnotetext{
Authors are research associate and professor, Department of Range Science, Texas A\&M University, College Station 77843.

This report is published as Technical article No. 16093 from the Texas Agricultural Experiment Station.

Manuscript received June $18,1980$.
}

Mature range forages (predominantly grasses) may be deficient in $K$, and $K$ supplements have been shown to increase cow and calf weights and conception rates (Kothman and Hinnant 1976, Karn and Clanton 1977, Waggoner et al. 1979). Potassium deficient diets have been reported for cows grazing dormant vegetation on the Coastal Prairie of Texas (Kothmann and Hinnant 1976). This study was conducted to determine the $K$ content of root, crown, leaf, and stem in three warm-season grasses from fall dormancy to initiation of growth in the spring. Potassium content of intact and frost damaged grasses was also investigated to determine the susceptibility of $\mathbf{K}$ to leaching by rainfall.

\section{Materials and Methods}

Two experiments were designed to monitor $K$ content from plant senescence in the fall until growth initiation in the spring, and to determine the leaching potential of intact and frost damaged plants. Little bluestem, kleingrass and brownseed paspalum were collected as representative warm-season perennial grasses which are commonly grazed during the winter. Little bluestem was collected from a roadside area in a little bluestem/splitbeard bluestem (Andropogon ternarius Michx.) dominated community in the post-oak savannah near College Station, Texas. Brownseed paspalum and kleingrass were collected from a plant nursery. Potassium content of the soils of the areas ranged from 104 to $188 \mathrm{ppm}$.

\section{Experiment I}

The first experiment was initiated prior to frost in November to monitor $K$ content of leaf, stem, crown, and root during two successive winters. Whole plant samples were collected at approximate monthly intervals. Soil was removed from crown and roots by a rapid wash in tapwater. The plants were separated into three parts; herbage, crown, and root. Plants were frozen at $-5^{\circ} \mathrm{C}$ and subsequently freeze-dried prior to analysis. The herbage was separated into leaf and stem and all four plant parts were ground to pass through a $1-\mathrm{mm}$ screen. Samples of each plant part were analyzed for $K$ with a modification of an acid extraction method (Horwitz 1975). Ground sample $(0.5 \mathrm{~g})$ was placed into a $100-\mathrm{ml}$ volumetric flask, shaken for approximately $15 \mathrm{~min}$ with $75 \mathrm{ml}$ of a $10 \% \mathrm{v} / \mathrm{v}$ solution of $\mathrm{H}_{2} \mathrm{SO}_{4}$, and then brought to volume. The sample was then filtered and analyzed by flame emission at $404 \mathrm{~m} \mu$ wavelength.

\section{Experiment II}

A second experiment was designed to determine the effect of leaching on $\mathrm{K}$ removal from fresh and frost simulated (frozen) grasses. Herbage of the three grasses was collected prior to frost in November 1975 for two treatments. In treatment one, fresh herbage was soaked in tapwater in stainless steel buckets for five time intervals (control or no-soak, 10,30,60, and $90 \mathrm{~min}$ ). In the second treatment, fresh herbage was placed in a freezer at $-20^{\circ}$ Covernight and then subjected to the same soaking treatments. Following each soaking treatment, the herbage was frozen, freeze-dried, and separated into leaf and stem. Potassium was analyzed as in experiment 
Table 1. Potassium content (\%) of leaf material of three plant species across six sampling dates during two winters.

\begin{tabular}{|c|c|c|c|c|c|c|}
\hline $\begin{array}{c}\text { Species } \\
\text { Year }\end{array}$ & Nov. & Dec. & Jan. & Feb. & Mar. & Apr. \\
\hline $\begin{array}{c}\text { Little bluesten } \\
\begin{array}{c}1975-76 \\
1976-77\end{array}\end{array}$ & $.34^{\mathrm{lm}}$ & $\begin{array}{l}.26^{\mathrm{m}} \\
.28^{\mathrm{m}}\end{array}$ & $\begin{array}{l}.29^{\mathrm{m}} \\
.30^{\mathrm{m}}\end{array}$ & $\begin{array}{l}.33^{\mathrm{lm}} \\
.35^{\mathrm{klm}}\end{array}$ & $\overline{.50^{j k l}}$ & $\begin{array}{l}\mathrm{J} .4 \mathrm{~J}^{\mathrm{cd} 1} \\
.88^{\mathrm{gh}}\end{array}$ \\
\hline $\begin{array}{l}\text { Kleingrass } \\
1975-76 \\
1976-77\end{array}$ & $\begin{array}{r}1.44^{c} \\
-\end{array}$ & $\begin{array}{r}1.75^{\mathrm{b}} \\
.21^{\mathrm{m}}\end{array}$ & $\begin{array}{c}1.27^{\mathrm{de}} \\
.30^{\mathrm{m}}\end{array}$ & $\begin{array}{r}1.13^{\mathrm{ef}} \\
.22^{\mathrm{m}}\end{array}$ & $1 . \overline{22^{\circ}}$ & $\begin{array}{l}2.06^{\mathrm{a}} \\
1.50^{\mathrm{c}}\end{array}$ \\
\hline $\begin{array}{c}\text { Brownseed pa } \\
1975-76 \\
1976-77\end{array}$ & $\begin{array}{c}.99^{f g} \\
-\end{array}$ & $\begin{array}{l}.78^{\mathrm{hi}} \\
.51^{\mathrm{jk}}\end{array}$ & $\begin{array}{l}.73^{\mathrm{hi}} \\
.33^{\mathrm{lm}}\end{array}$ & $\begin{array}{l}.52^{\mathrm{j}} \\
.28^{\mathrm{m}}\end{array}$ & $\overline{.49^{j k 1}}$ & $\begin{array}{r}1.44^{\mathrm{c}} \\
.69^{\mathrm{i}}\end{array}$ \\
\hline
\end{tabular}

'Means followed by the same letter do not differ significantly $(P<.05)$.

one.

Data from both experiments were analyzed by least squares analysis of variance techniques (Barr et al. 1976). Duncan's new multiple range test was used for mean separation (Duncan 1955).

\section{Results and Discussion}

\section{Experiment I}

Weather differed considerably during the two winters, causing variations in the $K$ content of herbage from two of the three species. The second winter had approximately two times more precipitation $(41.6 \mathrm{~cm})$ than the first winter $(20.7 \mathrm{~cm})$. Temperatures the second winter were more severe with 37 days of $0^{\circ} \mathrm{C}$ or below; whereas, the first winter had only 27 days of $0^{\circ} \mathrm{C}$ or below. The first killing frost (below $-4^{\circ} \mathrm{C}$ at $1.2 \mathrm{~m}$ ) occurred on November 23, 1975, and November 29, 1976.

Potassium content did not differ significantly between leaf and stem tissue, or between crown and root tissue when averaged across species, winters, and dates. The $\mathrm{K}$ content of leaf and stem tissue (herbage) $(.77 \%)$ was significantly higher than crown and root tissue $(.60 \%)$.

The mean $\mathrm{K}$ contents of leaf and stem were strongly affected by sampling date. Potassium contents of leaf and stem tissue were significantly higher in April than November (Table I and 2). Both April and November were significantly higher than December through March for stem tissue and December through February for leaf tissue. Potassium decreased from November through February and then increased significantly by April with initiation of spring growth. The interaction of plant parts by sampling dates was significant.

There were no significant differences among sampling dates in the $K$ content of crown and root tissue averaged across the three species. Potassium content of root and crown material did not increase during fall or as growth was initiated in the spring. Potassium in the roots appeared to be in equilibrium with the soil and thus translocation downward in the fall and upward in spring was not reflected by increased concentration.
Leaf tissue of kleingrass and brownseed paspalum contained significantly higher levels of $\mathrm{K}$ than the herbage of little bluestem during the winter of 1975-76 until April (Table 1). Little bluestem had reached senescence by November and the $K$ content of leaf and stem did not vary significantly either winter until March and April (Tables $\mathbf{l}$ and 2 ). The $\mathbf{K}$ content of little bluestem leaves remained at or below $0.55 \% \mathrm{~K}$ until April. Levels of $\mathbf{K}$ in herbage remained below the requirement of cattle until initiation of spring growth.

Kleingrass leaves had the highest amount of $K$ in November, but decreased approximately $50 \%$ by February before increasing in March and April (Table 2). Kleingrass was the species most affected by winter weather. Kleingrass retained some green foliage the first winter with actively growing basal leaves. Potassium content of leaves declined 35\% from December to February, but remained above $1.0 \%$. The $\mathrm{K}$ content of stems declined approximately $37 \%$ dropping to $0.53 \%$ by February (Table 2). Green herbage was less evident during the second winter as compared to the first winter. Potassium values remained below $0.30 \%$ in leaf and stem from December through February. Kleingrass has the potential to retain green leaves throughout mild winters, thus retaining adequate levels of potassium. During severe winters which produce dormant vegetation, the $K$ content of kleingrass may be below levels required by cattle.

Brownseed paspalum herbage lost approximately $50 \%$ of its $\mathrm{K}$ from November to February both winters (Tables 1 and 2). $K$ values were 0.99 and $1.80 \%$ for leaf and stem, respectively, prior to frost in 1975 , but decreased to below $0.60 \%$ by February. The second winter, leaf tissue remained at or below $0.50 \%$ until April and stem tissue declined from $0.70 \%$ in December to $0.58 \%$ in March. The $\mathrm{K}$ content of herbage increased to above $0.60 \%$ by April both winters. Brownseed paspalum, like kleingrass, contained higher levels of $K$ the first winter.

Herbage of all three species, with the exception of kleingrass leaves during the 1975-1976 winter, reached low levels of $\mathrm{K}$ which could be deficient or marginally deficient for cattle. Leaves and stems followed approximately the same trends with minor varia-

Table 2. Potassium content (\%) of stem material of three plant species across six sampling dates during two winters.

\begin{tabular}{|c|c|c|c|c|c|c|}
\hline $\begin{array}{c}\text { Species } \\
\text { Year } \\
\end{array}$ & Nov. & Dec. & Jan. & Feb. & Mar. & Apr. \\
\hline \multicolumn{7}{|l|}{ Little bluestem } \\
\hline $1975-76$ & $.55^{\mathrm{ijk} \operatorname{lm}}$ & $.33^{\mathrm{lmn}}$ & $.38^{\mathrm{kimn}}$ & $.22^{\mathrm{n}}$ & - & $1.63^{c^{1}}$ \\
\hline $1976-77$ & - & $.38^{\mathrm{klmn}}$ & $.48^{\mathrm{ijk} \mathbf{k} n \mathbf{n}}$ & $.38^{\mathrm{k} \operatorname{lm} n}$ & $.40^{\mathrm{jklmn}}$ & $.67^{\mathrm{hij}}$ \\
\hline \multicolumn{7}{|l|}{ Kleingrass } \\
\hline $1975-76$ & $1.36^{d}$ & $.94^{\mathrm{efg}}$ & $.57^{\mathrm{hijk} \mathbf{l}}$ & $.53^{\mathrm{jiklm}}$ & - & $2.81^{\mathrm{a}}$ \\
\hline $1976-77$ & - & $.29^{\operatorname{lmn}}$ & $.20^{\mathrm{n}}$ & $.22^{\mathrm{n}}$ & $.27^{\mathrm{mn}}$ & $.97^{e f}$ \\
\hline \multicolumn{7}{|c|}{ Brownseed paspalum } \\
\hline $1975-76$ & $1.80^{c}$ & $1.13^{\mathrm{de}}$ & $.71^{\mathrm{ghi}}$ & $.58^{h \mathrm{hjk} \mathbf{l}}$ & - & $2.39^{\mathrm{b}}$ \\
\hline $1976-77$ & - & $.73^{\mathrm{fghi}}$ & $.63^{\mathrm{hijk}}$ & $.52^{\mathrm{j} \mathrm{jk} \operatorname{lm}}$ & $.46^{\mathrm{ijk} \operatorname{lm} n}$ & $.83^{\mathrm{fgh}}$ \\
\hline
\end{tabular}

IMeans followed by the same letter do not differ significantly $(\mathcal{P}<.05)$ 
tions in rates, dates, and severity of decline. During early spring of 1977 , only kleingrass herbage had K levels significantly above the requirements of cattle. Little bluestem and brownseed paspalum leaves were slower to initiate growth during the second spring.

\section{Experiment II}

Leaf and stem material responded similarly to soaking treatments and discussion will be limited to herbage of the three species. Freshly clipped herbage (averaged across species) was not significantly affected by different soaking intervals (Table 3 ). Fresh samples contained approximately the same amount of $K$ after the 90-min soak as the no-soak. In the frost simulated (frozen) herbage, $\mathrm{K}$ losses were significant (Table 3 ). After 10 min of soaking, $\mathrm{K}$ content was significantly lower than in the control of fresh foliar material. Frozen plants with damaged cells lost $\mathbf{K}$ readily.

Table 3. Potassium content (\%) of fresh and frozen herbage following five soaking treatments to evaluate leaching potential.

\begin{tabular}{llllll}
\hline \hline Foliage & \multicolumn{5}{c}{ Soaking treatment } \\
\cline { 2 - 6 } pre-treatment & $0 \mathrm{~min}$ & $10 \mathrm{~min}$ & $30 \mathrm{~min}$ & $60 \mathrm{~min}$ & $90 \mathrm{~min}$ \\
\hline Fresh foliage & $1.03^{\mathrm{b}}$ & $1.04^{\mathrm{b}}$ & $.95^{\mathrm{b}}$ & $1.03^{\mathrm{b}}$ & $1.06^{\mathrm{b}^{\mathrm{b}}}$ \\
Frozen foliage & $1.23^{\mathrm{a}}$ & $.92^{\mathrm{bc}}$ & $.74^{\mathrm{d}}$ & $.80^{\text {od }}$ & $.68^{\mathrm{a}}$ \\
\hline
\end{tabular}

'Means followed by the same letter do not differ significantly $(P<.05)$,

The $\mathrm{K}$ content of little bluestem was significantly lower than kleingrass and brownseed paspalum in all soaking intervals. There were no significant differences between time intervals of soaking for either treatment of little bluestem (Table 4), reflecting the depleted $\mathbf{K}$ content of the species by November. The $\mathrm{K}$ content of fresh kleingrass and brownseed paspalum herbage soaked up to 90 min did not differ significantly from the no-soak treatment. Fluctuations occurred in the fresh herbage possibly due to changes in $\mathrm{K}$ content of active plant cells. Potassium content of frozen herbage of brownseed paspalum and kleingrass declined significantly after 30 min soaking and then remained stable through the 90-min treatment. Thus, kleingrass and brownseed paspalum are susceptible to leaching during rainy periods following frost.

Table 4. Potassium content (\%) of fresh and frozen herbage of three species on five soaking treatments to evaluate potential leaching.

\begin{tabular}{|c|c|c|c|c|c|}
\hline \multirow{2}{*}{$\begin{array}{l}\text { Species/ } \\
\text { pre-treatment }\end{array}$} & \multicolumn{5}{|c|}{ Soaking treatments } \\
\hline & $0 \min$ & $10 \mathrm{~min}$ & $30 \mathrm{~min}$ & $60 \mathrm{~min}$ & $90 \mathrm{~min}$ \\
\hline $\begin{array}{l}\text { Little bluestem } \\
\text { Fresh } \\
\text { Frozen }\end{array}$ & $\begin{array}{l}.37^{\mathrm{i}} \\
.45^{\mathrm{i}}\end{array}$ & $\begin{array}{l}.29^{\mathrm{i}} \\
.30^{\mathrm{i}}\end{array}$ & $\begin{array}{l}.23^{\mathrm{i}} \\
.27^{\mathrm{i}}\end{array}$ & $\begin{array}{l}.33^{\mathrm{i}} \\
.35^{\mathrm{i}}\end{array}$ & $\begin{array}{l}.27^{i^{1}} \\
.22^{i}\end{array}$ \\
\hline $\begin{array}{c}\text { Kleingrass } \\
\text { Fresh } \\
\text { Frozen }\end{array}$ & $\begin{array}{l}1.37^{\text {bed }} \\
1.77^{a}\end{array}$ & $\begin{array}{l}1.51^{\mathrm{bc}} \\
1.19^{\mathrm{def}}\end{array}$ & $\begin{array}{l}1.28^{\text {cde }} \\
1.09^{\text {efg }}\end{array}$ & $\begin{array}{l}1.46^{\mathrm{bc}} \\
1.09^{\mathrm{efsh}}\end{array}$ & $\begin{array}{l}1.55^{b} \\
.96^{f a h}\end{array}$ \\
\hline $\begin{array}{c}\text { Brownseed pas } \\
\text { Fresh } \\
\text { Frozen }\end{array}$ & $\begin{array}{l}1.35^{\mathrm{bcd}} \\
1.46^{\mathrm{bc}}\end{array}$ & $\begin{array}{l}1.32^{\text {bede }} \\
1.28^{\text {ede }}\end{array}$ & $\begin{array}{l}1.35^{\mathrm{bcd}} \\
.85^{\mathrm{h}}\end{array}$ & $\begin{array}{c}1.31^{\text {bede }} \\
.95^{\text {fgh }}\end{array}$ & $\begin{array}{r}1.36^{\mathrm{bcd}} \\
.87^{\mathrm{gh}}\end{array}$ \\
\hline
\end{tabular}

'Means followed by the same letter do not differ significantly $(P<.05)$.

\section{Conclusions}

Potassium content of grasses can fall to levels significantly less than 0.6 to $0.8 \%$ during the winter, potentially lending to $\mathrm{K}$ deficient diets for cattle. Little bluestem typically reaches senescence with very little new growth, and $\mathrm{k}$ is translocated and readily leached early in the fall. Kleingrass and brownseed paspalum produce some new foliage during mild winters and adequate $K$ levels are maintained until the plants are damaged by frost. These grasses are highly susceptible to leaching after frost, and $\mathrm{K}$ is lost at a rapid rate. Potassium deficiencies would be more likely in cold wet winters than mild dry winters. Potassium supplement is needed in areas where cattle graze dormant predominantly warm-season grasses. Potassium content of these grasses increased rapidly as plants began spring growth.

\section{Literature Cited}

Barr, A.J., J.H. Goodnight, J.S. Sall, and J.R. Helwig. 1976. A User's Guide to S.A.S. 76. S.A.S. Institute Inc., Raleigh, N. Carolina. 494 p.

Burroughs, W.(ch). 1976. Nutrient Requirements of Beef Cattle. Nat. Acad. of Sci.-Nat. Res. Coun. Nutrient Requirements of Domestic Animals. No. 4. Washington, D.C. 55 p.

Church, D.C., (ed.). 1971. Digestive physiology and nutrition of ruminants. Volume II-Nutrition. O\&B Books, Inc., Corvallis, Oregon. 693 p.

Clement, C.R., L.H.P. Jones, and M.J. Hopper. 1972. Leaching of some elements from herbage plants by simulated rain. J. App. Eco. 9:249-259.

Davis, D.L., R.E. Brown, and D.E. Beitz. 1964. Effects of feeding high grain restricted-roughage rations with and without bicarbonates on the fat content of milk produced and proportions of volatile fatty acids in the rumen. J. Dairy Sci. 47:1217-1223.

Duncan, D.B. 1955. Multiple range and multiple $F$ tests. Biometrics. 11:1-42.

Emery, R.S., L.D. Brown, and J.W. Bell. 1965. Supplementing restricted roughage rations with magnesium oxide or sodium bicarbonate prevents milk fat depession. J. Dairy Sci. 48:809.

Horwitz, W., (ed.). 1975. Official Methods of Analysis of the Association of Official Analytical Chemists. (11th Ed.) Association of Official Agricultural Chemists. Washington, D.C. 1094 p.

Karn, J.F., and D.C. Clanton. 1977. Potassium in range supplements. J. Anim. Sci. 45:1426-1434.

Kothmann, M.M., and R.T. Hinnant. 1976. Winter nutrition for cow-calf operations in the Coastal Prairie. Proc. Annu. Meeting. Soc. Range Manage. (Abstract) p. 58-59.

Lawton, K., and R.L. Cook. 1954. Potassium in plant nutrition. Advan. Agron. 6:253-306.

Thompson, D.J. 1972. Potassium in animal nutrition. Technical servicesanimal health and nutrition div. International Minerals and Chemical Corp. Libbertyville, Ill. 47 p.

Tisdale, S.L., and W.L. Nelson. 1968. Soil fertility and fertilizers. The MacMillan Co. New York. 694 p.

Tukey, H.B., Jr., and H.J. Amlug. 1958. Leaching of forage by rain and dew as an explanation of differences in the nutrient composition of greenhouse and field-grown plants. Michigan Agr. Exp. Sta. Quart. Bull. 40:876-881.

Waggoner, J.W., Jr., C.C. Kaltenback, W.W. Smith, T.R. Varnell, D.H. Clark, S.L. Applegate, G.E. Nelms, and H.D. Radloff. 1979. Potassium in the winter supplement of range beef cows. Proc. West. Sec. Amer. Soc. Anim. Sci. 30:284.

Ward, G.M. 1966. Potassium metabolism of domestic ruminants-a review. J. Dairy Sci. 49:268-276.

Woodhouse, W.W., Jr., and W.K. Griffith. 1969. Soil fertility and the fertilization of forages. In: Forages. Hughes, H.D., M.E. Heath, and D.S. Metcalf (eds). The lowa State Univ. Press. Ames lowa. p. 403-415. 